\title{
Ethnic differences in consultation rates in urban general practice
}

\author{
S J Gillam, B Jarman, P White, R Law
}

\begin{abstract}
Objective-To determine the patterns of consultations with the general practitioner among different ethnic groups and the outcome of these consultations.

Design-Retrospective analysis of data from one urban group general practice collected during 197981 as part of a research project in seven practices.

Setting-Group general practice in the London borough of Brent with a list size of 10877 patients in July 1980 .

Subjects-Patients registered with the practice during the 23 months to April 1981 who accounted for 67197 consultations.
\end{abstract}

Main outcome measures-Ethnic state, sex and social class distribution, and diagnosis of patients consulting and frequency of consultations analysed as standardised consultation ratios and standardised patient consultation ratios.

Results-Compared with other ethnic groups male Asians (that is, including those born in Britain and those originating from the Indian subcontinent and east Africa) had a substantially increased standardised patient consultation ratio. Consultation rates for mental disorders-in particular, anxiety and depression - were reduced in all groups of immigrant descent. West Indians consulted more frequently for hypertension and asthma, and their children less frequently with otitis media. Asians consulted more frequently with upper respiratory tract infections and non-specific symptoms. Native British patients were more likely to leave the surgery with a follow up appointment, prescription, or certificate.

Conclusion-Notwithstanding the limitations of this study, ethnic differences in consultation rates were apparent. These differences require further investigation if the needs of minority ethnic groups are not to be overlooked.

\section{Department of General Practice, St Mary's Hospital Medical School, Lisson Grove Health Centre, London NW8 8EG S J Gillam, MRCP, lecturer B Jarman, FRCP, professor $\mathrm{P}$ White, BTECH, research assistant}

\section{London NW10}

R Law, FRCGP, general practitioner

Correspondence to: Dr Gillam.

\section{Introduction}

Surprisingly little is known of the health state of Britain's ethnic minorities, and the evidence available shows a medical bias. Research and planning have often been preoccupied with conditions specific to minority ethnic groups, such as rickets, osteomalacia, thalassaemia, sickle cell anaemia, and tuberculosis. The limitations of this approach are obvious. Though these diseases require specialised services, they affect comparatively few people and may deflect attention from more widespread needs. Community surveys suggest more commonplace preoccupations - for example, with asthma, infertility, and psychosexual problems.'

There are various, well recognised ethnic differences in the incidences of certain diseases commonly encountered in general practice-namely, hypertension, diabetes mellitus, and cerebrovascular and ischaemic heart disease-but little is known of how these differences are reflected in consultation patterns. Pinsent noted higher consultation rates for most problems among Afro-Caribbean patients, ${ }^{2}$ whereas later Carne found no overall differences. ${ }^{3}$ In neither study were rates standardised or socioeconomic data presented. The Royal College of General Practitioners' study of 1970-1 found increased standardised consultation ratios among patients from India and Pakistan. ${ }^{+}$Murray and Williams found that Asian men - that is, men born in the Indian subcontinent were more likely to have seen their general practitioner during the previous fortnight. Some evidence suggests greater use of medical services by elderly Asians and West Indians, "but other studies have failed to identify significant differences in the demand for primary health care. These conflicting results underline the importance of maintaining a historical perspective. The needs and expectations of minority ethnic groups are likely to change substantially over a generation.

This study was designed to investigate patterns of consultations and their outcome among different ethnic groups in one urban practice that had undergone demographic transformation over the previous 35 years. The senior partner (RL) had seen the proportion of patients of United Kingdom descent registered with the practice decline from over $90 \%$ in 1953 to $35 \%$ in 1988. The consultation patterns of different populations had changed substantially over that time.

\section{Methods}

The study was part of a larger research project on prescribing workload and morbidity in seven London general practices carried out between 1979 and $1981 .{ }^{\circ}$ The practice concerned is situated in Brent, which has the lowest proportion of residents born to native Britons of all London boroughs $(67 \%)$. The doctors were all graduates of British medical schools. Details of each consultation and outcome were entered on a worksheet, which provided space for up to two diagnoses. These were classified by using the ninth revision of the International Classification of Diseases (ICD), 1975.

The ethnic classification adopted, after discussion with the Office of Population Censuses and Surveys, combined race and nationality. Priority was accorded to race in the case of east African born Asians. The limitations of any such classification are acknowledged.

To take account of differences in the age structure of the different groups consultation rates were standardised indirectly by using the practice's rates for native British patients as the standard. For each ethnic group the expected numbers of consultations a year in each age band $(0-4,5-16,17-24,25-34,35-44,45-54$, $55-64,65-74, \geqslant 75$ years) were summated. The total number of consultations observed was divided by the total number expected to give a standardised consultation ratio. ${ }^{10}$ This compared total attendances and was a crude index of workload. Differences could 
be accounted for by different consultation behaviours among groups if, for example, one group consulted more often per episode of illness. A better indication of differences in morbidity among groups was the patients' consultation rate - that is, the number of people consulting with a particular condition each year per person at risk. This was standardised in the same way to give a standardised patient consultation ratio. Differing perceptions of severity or the need for treatment as well as real differences in morbidity may influence the decision to consult a general practitioner. The statistical significance of the differences between standardised consultation ratios and standardised patient consultation ratios for each group was derived from standard normal deviates (see appendix). The

TABLE I - Ethnic distribution of patients registered with practice in fuly 1980

\begin{tabular}{lcc}
\hline Ethnic state of patients & No & $" \%$ \\
\hline Native British (born to parents of United Kingdom descent) & 3846 & 35 \\
Southern Irish (including United Kingdom born, of southern Irish parents) & $1769(660)$ & 16 \\
Other European (including United Kingdom born, of "other European" parents & $988(435)$ & $9(4)$ \\
West Indian (including United Kingdom born, of W'est Indian parents) & $2423981)$ & $22(9)$ \\
Asian (including United Kingdom born, of Asian parents) & $1088(324)$ & $10(3)$ \\
Other & 763 & 7 \\
\hline Total & 10877 & 99
\end{tabular}

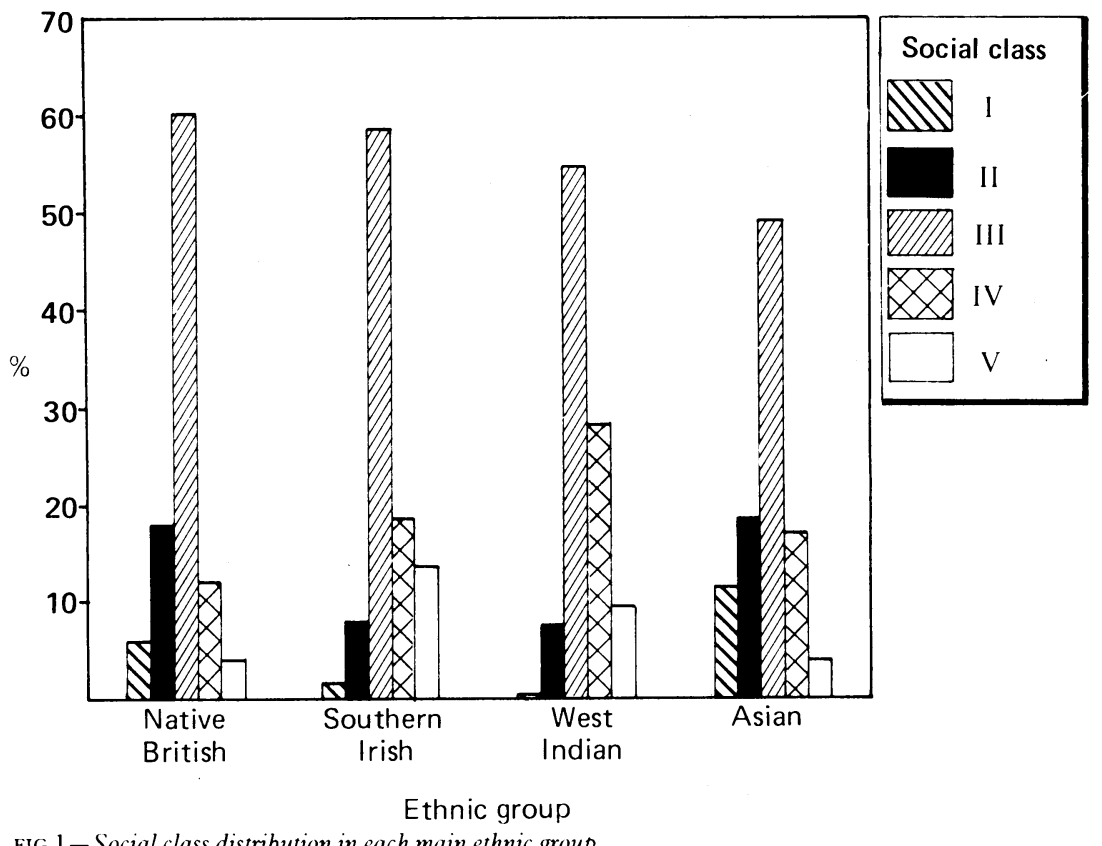

FIG 1 -Social class distribution in each main ethnic group

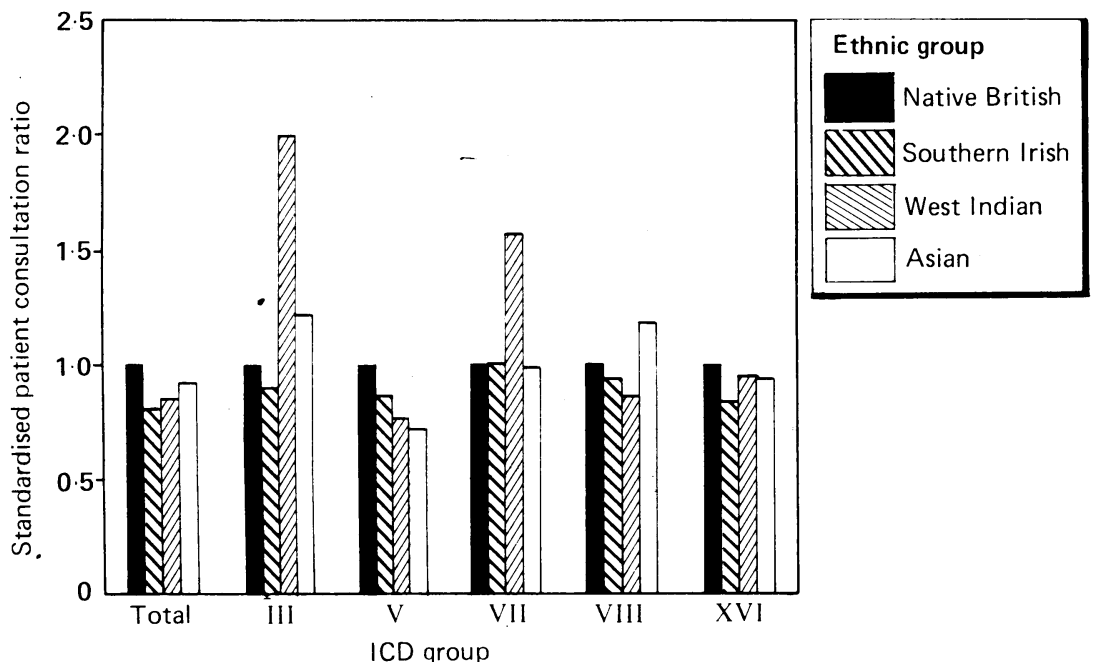

FIG 2-Female standardised patient consultation ratios by ethric group. ICD groups defined as: $I I I=$ endocrine, nutritional, and metabolic diseases; $V=$ mental disorders; $V I I=$ diseases of the circulatory system; VIII = diseases of the respiratory system; $X V I=$ symptoms and ill defined conditions classifications and age bands used were those endorsed by the Royal College of General Practitioners in the national morbidity study but with all those over 75 grouped into one band. The population denominator was calculated in terms of the number of person months at risk.

\section{Results}

In July 1980 there were 10877 patients registered with the practice. The total number of consultations recorded over the 23 months to April 1981 was 67 197. Table I shows the ethnic distribution of patients registered with the practice and figure 1 the socioeconomic structure of the four main groups studied. These were native British patients (that is, people born to parents of United Kingdom descent), southern Irish patients (that is, including patients born in the United Kingdom to citizens of the Republic of Ireland), West Indians (including those born in the United Kingdom to West Indian parents), and Asians (including east African born Asians and those born in the United Kingdom to parents from the Indian subcontinent).

For all diagnoses combined the standardised consultation ratios and standardised patient consultation ratios of Irish and West Indian patients were reduced. The standardised consultation ratio but not the standardised patient consultation ratio was increased among Asians-that is, patients' consulting rates were similar but those who did consult did so more frequently. Figures 2 and 3 show the standardised patient consultation ratios in each of the main disease groups among male and female patients. Figures 4 and 5 show the standardised consultation ratios discussed in the text. Only those differences significant at the $1 \%$ level or of greater significance are referred to below.

Standardised consultation ratios and standardised patient consultation ratios for infective and parasitic diseases (ICD group I) were reduced among the Irish and West Indian patients.

Standardised patient consultation ratios for endocrine, nutritional, and metabolic diseases (ICD group III) were increased among female West Indian and male Asian patients. This was mainly due to an increased standardised patient consultation ratio in the same groups for diabetes mellitus, but the numbers were small.

Standardised patient consultation ratios for mental disorders (ICD group V) were greatly reduced among female Asian and West Indian patients $(0.72$ and 0.76 respectively). Standardised patient consultation ratios for the two most commonly diagnosed conditions, depression and anxiety, were also reduced relative to native British patients among West Indians and female Asians.

There was a reduction in the standardised patient consultation ratio for diseases of the nervous system and sense organs (ICD group VI) among patients of West Indian origin. In part this was due to a highly significant reduction in the standardised patient consultation ratio for otitis media in this group (table II).

Standardised consultation ratios for all diseases of the circulatory system (ICD group VII) were increased among West Indians and male Asians but standardised patient consultation ratios only among West Indian women. These differences were in part explained by increased standardised consultation ratios among West Indians for the commonest diagnosis, hypertension. Standardised patient consultation ratios for hypertension were significantly higher only among West Indians.

Standardised consultation ratios for diseases of the respiratory system (ICD group VIII) were greatly raised 


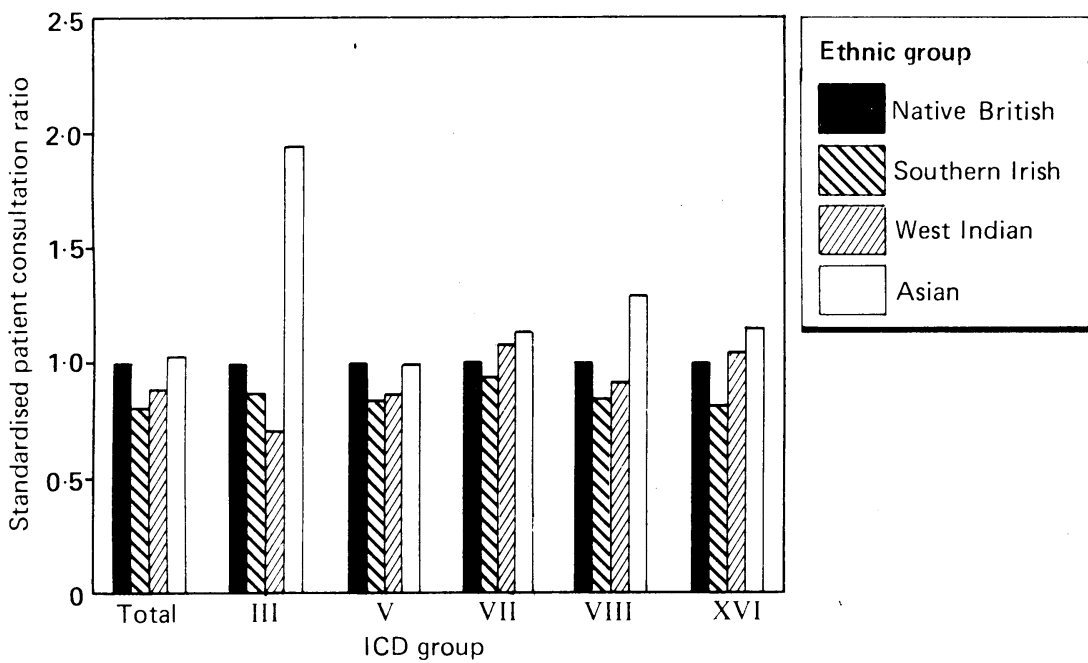

FIG 3-Male standardised patient consultation ratios by ethnic group. ICD groups defined in fig 2

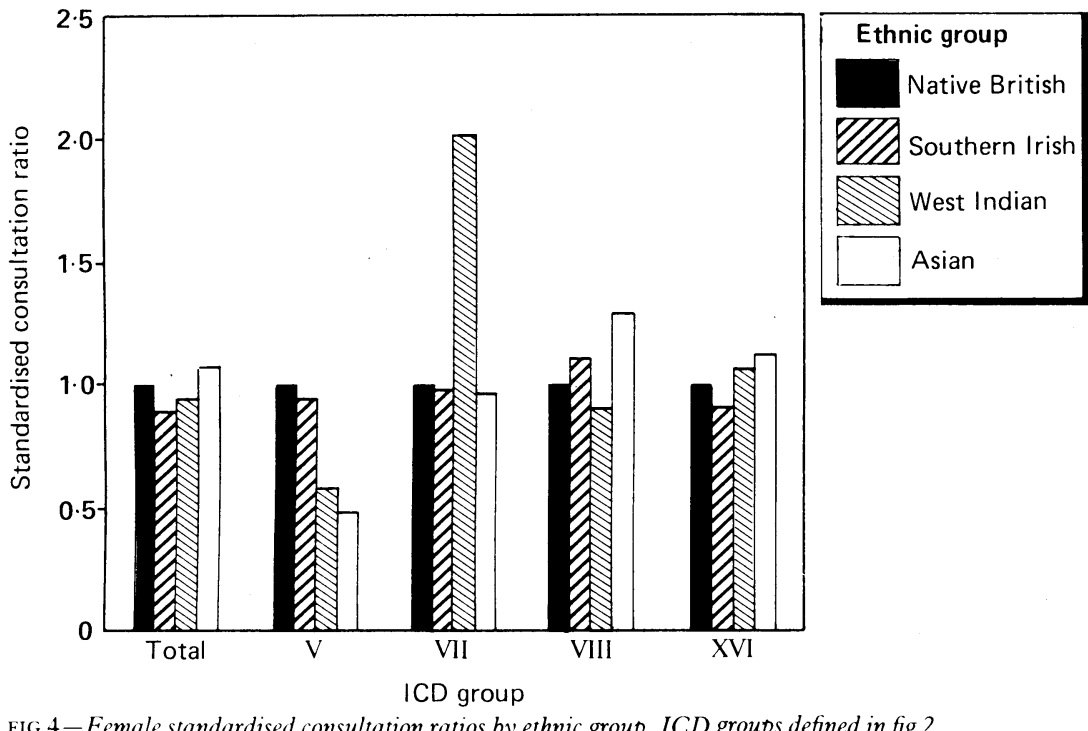

FIG 4-Female standardised consultation ratios by ethnic group. ICD groups defined in fig 2

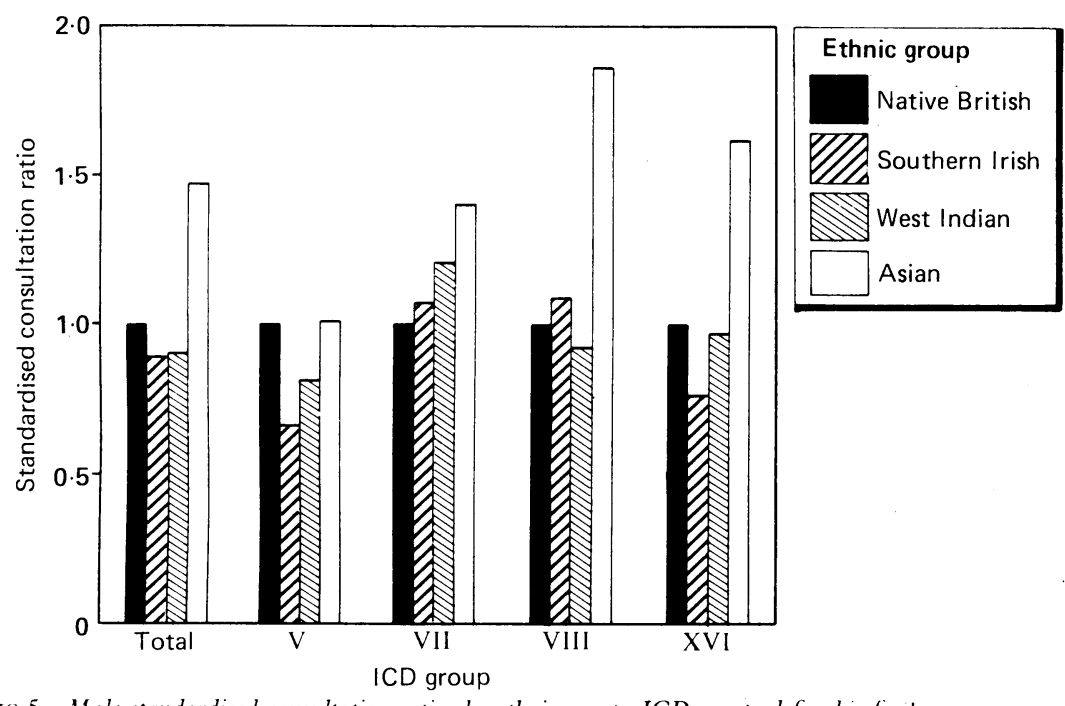

FIG 5-Male standardised consultation ratios by ethnic group. ICD groups defined in fig 2

among Irish and Asian patients, but standardised patient consultation ratios were raised only among Asians. Adult Asians consulted much more frequently with upper respiratory tract infection, the commonest diagnosis in this group. The standardised patient consultation ratio among Asian children was raised, but West Indian children presented less frequently with upper respiratory tract infections. Standardised patient consultation ratios for all respiratory diseases were reduced among female West Indian patients, most significantly for acute bronchitis. Standardised consultation ratios for asthma were raised among West Indians and Asians. Standardised patient consultation ratios were significantly raised only among female West Indian patients and Asian males. Similarly, West Indians and male Asian patients attended more frequently with allergic rhinitis and hay fever, but standardised patient consultation ratios were significantly raised only among West Indians.

There were no great differences in consultation rates for diseases of the digestive system (ICD group IX). Gastroenteritis is included in ICD group I.

Other than an unexplained reduction among Irish patients in the standardised patient consultation ratio for diseases of the genitourinary system (ICD group $\mathrm{X}$ ) rates were similar for all ethnic groups.

Overall consultation rates for diseases of the skin and subcutaneous tissues (ICD group XII) were similar in all groups, but standardised consultation ratios for eczema, the commonest, were significantly raised among West Indian children (table II).

Irish patients consulted less often for diseases of the musculoskeletal system and connective tissue (ICD group XIII). Among female West Indian and all Asian patients there were significantly higher standardised patient consultation ratios for back pain (table II).

For symptoms and ill defined conditions (ICD group XVI) standardised consultation ratios were reduced among Irish patients but raised among Asian patients. Standardised patient consultation ratios showed a significant reduction only among the Irish.

Native British patients were much more likely to leave the surgery with a follow up appointment. There was little variation among the groups in the proportions of patients given a prescription or certificate. Standardised home visiting rates were significantly lower among Irish and West Indian patients.

\section{Discussion}

These findings need to be considered in the light of certain methodological limitations. Too much weight cannot be attached to findings in categories in which numbers were small. Consultation rates among the under $5 \mathrm{~s}$ will be slightly distorted by infants registered for less than a year. Though differences in social class distribution among the ethnic groups were not great (fig 1), they were not standardised. Patients in lower social classes tend to consult more frequently. ${ }^{+}$Asians, however, were overrepresented in classes I and II, and West Indians and Irish were overrepresented in classes IV and V. Thus the failure to standardise for social class does not explain the findings. The results may conceal differences in coding or recording practices. Nevertheless, several differences emerge, not all of which reflect known differences in morbidity among ethnic groups.

Reduced consultation rates for mental disorders, in particular anxiety and depression, were found among patients of immigrant descent, especially women. Community surveys suggest that Asian immigrants suffer less psychological disorder than native English. " Asians have considerably lower rates of admission for psychiatric care. ${ }^{12}$ This has been attributed to "positive selection" of the ablest and most healthy in migrating. " On the other hand, Brewin found similar rates of consultation with the general practitioner among matched samples of patients of Asian and English origin and suggested that "factors affecting doctorpatient interaction" are responsible for Asians' underutilisation of facilities. ${ }^{1+}$ Psychological distress may be less readily recognised in Asians. Our findings 
TABLE II - Standardised consultation ratios (SCR) and standardised patient consultation ratios (SPCR) by diagnosis

\begin{tabular}{|c|c|c|c|c|c|c|c|c|c|}
\hline & & \multicolumn{2}{|c|}{ Native British } & \multicolumn{2}{|c|}{ Southern Irish } & \multicolumn{2}{|c|}{ West Indian } & \multicolumn{2}{|c|}{ Asian } \\
\hline & & $M$ & $\mathbf{F}$ & $M$ & $\mathrm{~F}$ & $M$ & $\mathrm{~F}$ & $M$ & $\mathrm{~F}$ \\
\hline Depression & $\left\{\begin{array}{l}\text { SCR } \\
\text { SPCR }\end{array}\right.$ & $\begin{array}{l}1 \cdot 00 \\
1 \cdot 00\end{array}$ & $\begin{array}{l}1 \cdot 00 \\
1 \cdot 00\end{array}$ & $\begin{array}{l}0 \cdot 39^{\star} \\
0 \cdot 70\end{array}$ & $\begin{array}{l}0 \cdot 80^{\star} \\
0 \cdot 85\end{array}$ & $\begin{array}{l}0 \cdot 43^{\star} \\
0 \cdot 47^{\star}\end{array}$ & $\begin{array}{l}0 \cdot 50^{\star} \\
0 \cdot 66\end{array}$ & $\begin{array}{l}0 \cdot 64 \\
0 \cdot 69\end{array}$ & $\begin{array}{l}0 \cdot 37^{\star} \\
0 \cdot 62^{\star}\end{array}$ \\
\hline Anxiety & $\left\{\begin{array}{l}\text { SCR } \\
\text { SPCR }\end{array}\right.$ & $\begin{array}{l}1 \cdot 00 \\
1 \cdot 00\end{array}$ & $\begin{array}{l}1 \cdot 00 \\
1 \cdot 00\end{array}$ & $\begin{array}{l}0.44^{\star} \\
0.63\end{array}$ & $\begin{array}{l}1 \cdot 03 \\
0 \cdot 81\end{array}$ & $\begin{array}{l}0 \cdot 56^{\star} \\
0 \cdot 66\end{array}$ & $\begin{array}{l}0 \cdot 53^{\star} \\
0.60^{\star}\end{array}$ & $\begin{array}{l}1 \cdot 19 \\
1 \cdot 03\end{array}$ & $\begin{array}{l}0 \cdot 40^{\star} \\
0 \cdot 50^{\star}\end{array}$ \\
\hline Hypertension & $\left\{\begin{array}{l}\text { SCR } \\
\text { SPCR }\end{array}\right.$ & $\begin{array}{l}1 \cdot 00 \\
1 \cdot 00\end{array}$ & $\begin{array}{l}1 \cdot 00 \\
1 \cdot 00\end{array}$ & $\begin{array}{l}1 \cdot 40^{\star} \\
1 \cdot 13\end{array}$ & $\begin{array}{l}1 \cdot 04 \\
1 \cdot 01\end{array}$ & $\begin{array}{l}2 \cdot 54^{\star} \\
2 \cdot 00^{\star}\end{array}$ & $\begin{array}{l}2 \cdot 90^{\star} \\
3 \cdot 00^{\star}\end{array}$ & $\begin{array}{l}1 \cdot 62^{\star} \\
0 \cdot 78\end{array}$ & $\begin{array}{l}1 \cdot 17 \\
1 \cdot 34\end{array}$ \\
\hline $\begin{array}{l}\text { Upper respiratory tract } \\
\text { infection }\end{array}$ & $\left\{\begin{array}{l}\text { SCR } \\
\text { SPCR }\end{array}\right.$ & $\begin{array}{l}1 \cdot 00 \\
1 \cdot 00\end{array}$ & $\begin{array}{l}1 \cdot 00 \\
1 \cdot 00\end{array}$ & $\begin{array}{l}0 \cdot 54^{\star} \\
0 \cdot 63^{\star}\end{array}$ & $\begin{array}{l}1 \cdot 17 \\
1 \cdot 05\end{array}$ & $\begin{array}{l}0 \cdot 80 \\
0 \cdot 82\end{array}$ & $\begin{array}{l}0.92 \\
0.95\end{array}$ & $\begin{array}{l}2 \cdot 84^{\star} \\
2 \cdot 43^{\star}\end{array}$ & $\begin{array}{l}1 \cdot 89^{\star} \\
1 \cdot 64^{\star}\end{array}$ \\
\hline Otitis media & $\left\{\begin{array}{l}\text { SCR } \\
\text { SPCR }\end{array}\right.$ & $\begin{array}{l}1 \cdot 00 \\
1 \cdot 00\end{array}$ & $\begin{array}{l}1 \cdot 00 \\
1 \cdot 00\end{array}$ & $\begin{array}{l}0 \cdot 94 \\
0 \cdot 95\end{array}$ & $\begin{array}{l}0 \cdot 84 \\
0.93\end{array}$ & $\begin{array}{l}0 \cdot 19^{\star} \\
0 \cdot 30^{\star}\end{array}$ & $\begin{array}{l}0 \cdot 21^{\star} \\
0 \cdot 34^{\star}\end{array}$ & $\begin{array}{l}0 \cdot 60^{\star} \\
0.83\end{array}$ & $\begin{array}{l}0 \cdot 84^{\star} \\
0 \cdot 80\end{array}$ \\
\hline Allergic rhinitis & $\left\{\begin{array}{l}\text { SCR } \\
\text { SPCR }\end{array}\right.$ & $\begin{array}{l}1 \cdot 00 \\
1 \cdot 00\end{array}$ & $\begin{array}{l}1 \cdot 00 \\
1 \cdot 00\end{array}$ & $\begin{array}{l}0 \cdot 78 \\
0.47^{\star}\end{array}$ & $\begin{array}{l}0 \cdot 45^{\star} \\
0 \cdot 48^{\star}\end{array}$ & $\begin{array}{l}1 \cdot 79^{\star} \\
1.56\end{array}$ & $\begin{array}{l}1 \cdot 90^{\star} \\
1 \cdot 82^{\star}\end{array}$ & $\begin{array}{l}1.92^{\star} \\
1.52\end{array}$ & $\begin{array}{l}1.01 \\
0.95\end{array}$ \\
\hline Asthma & $\left\{\begin{array}{l}\text { SCR } \\
\text { SPCR }\end{array}\right.$ & $\begin{array}{l}1 \cdot 00 \\
1 \cdot 00\end{array}$ & $\begin{array}{l}1 \cdot 00 \\
1 \cdot 00\end{array}$ & $\begin{array}{l}1 \cdot 30 \\
0 \cdot 92\end{array}$ & $\begin{array}{l}1 \cdot 30 \\
0 \cdot 95\end{array}$ & $\begin{array}{l}1.62^{\star} \\
1 \cdot 38\end{array}$ & $\begin{array}{l}1 \cdot 60^{\star} \\
1 \cdot 63^{\star}\end{array}$ & $\begin{array}{l}2 \cdot 27^{\star} \\
1 \cdot 75\end{array}$ & $\begin{array}{l}1 \cdot 60^{\star} \\
1 \cdot 42\end{array}$ \\
\hline Eczema & $\left\{\begin{array}{l}\text { SCR } \\
\text { SPCR }\end{array}\right.$ & $\begin{array}{l}1 \cdot 00 \\
1 \cdot 00\end{array}$ & $\begin{array}{l}1.00 \\
1.00\end{array}$ & $\begin{array}{l}0.85 \\
0.59\end{array}$ & $\begin{array}{l}1.05 \\
1.17\end{array}$ & $\begin{array}{l}1.51 \\
1.14\end{array}$ & $\begin{array}{l}2 \cdot 43^{\star} \\
2 \cdot 12^{\star}\end{array}$ & $\begin{array}{l}1 \cdot 37 \\
1 \cdot 24\end{array}$ & $\begin{array}{l}1.49 \\
1.17\end{array}$ \\
\hline Back pain & $\left\{\begin{array}{l}\text { SCR } \\
\text { SPCR }\end{array}\right.$ & $\begin{array}{l}1 \cdot 00 \\
1.00\end{array}$ & $\begin{array}{l}1.00 \\
1.00\end{array}$ & $\begin{array}{l}0.57^{\star} \\
0.80\end{array}$ & $\begin{array}{l}1 \cdot 22 \\
1.09\end{array}$ & $\begin{array}{l}1 \cdot 13 \\
1 \cdot 18\end{array}$ & $\begin{array}{l}1 \cdot 62^{\star} \\
1 \cdot 39^{\star}\end{array}$ & $\begin{array}{l}1 \cdot 54^{\star} \\
1 \cdot 71^{\star}\end{array}$ & $\begin{array}{l}2 \cdot 11^{\star} \\
1 \cdot 67^{\star}\end{array}$ \\
\hline Diabetes mellitus & $\left\{\begin{array}{l}\text { SCR } \\
\text { SPCR }\end{array}\right.$ & $\begin{array}{l}1.00 \\
1.00\end{array}$ & $\begin{array}{l}1.00 \\
1.00\end{array}$ & $\begin{array}{l}0.33^{\star} \\
1.08\end{array}$ & $\begin{array}{l}1 \cdot 23 \\
1.44\end{array}$ & $\begin{array}{l}2.91{ }^{\star} \\
2.99\end{array}$ & $\begin{array}{l}9 \cdot 90^{\star} \\
5 \cdot 49^{\star}\end{array}$ & $\begin{array}{l}6 \cdot 14^{\star} \\
8 \cdot 55^{\star}\end{array}$ & $\begin{array}{l}1.79 \\
2.99\end{array}$ \\
\hline
\end{tabular}

${ }^{\star}$ Standard normal deviate $>2 \cdot 58 ; \mathrm{p}<0 \cdot 01$.

may reflect both reduced mental disorder in the community and a failure to recognise psychological distress in the light of the higher than average overall standardised consultation ratio of Asian patients. Misinterpretation by the doctor and the recognised tendency to somatisation of psychological distress in some groups ${ }^{15}$ may contribute to the raised consultation rates for back pain among patients of West Indian and Asian descent

The high incidence of schizophrenia among West Indians is well established. ${ }^{16}{ }^{17}$ Depression is less often diagnosed, and inconsistencies in diagnostic practice may be a reason for this. ${ }^{18}$ There have been few community surveys of psychiatric morbidity in this group. Burke found higher rates of depression and psychosomatic disorder among Afro-Caribbeans than among white patients. ${ }^{19}$. Similarly, A Haines and colleagues, studying participants in the Northwick Park heart study, found evidence for a higher prevalence of psychiatric morbidity in the Afro-Caribbean community (personal communication). It seems that depressed West Indians seldom seek psychiatric treatment,,$^{20}$ but such generalisations must be treated cautiously. Kleinman used the term "category fallacy" for the inappropriate application of a diagnostic label developed for one cultural group to members of another for whom it lacks coherence or validity. ${ }^{21}$

Increased consultation rates for circulatory diseases among Asians and West Indians are not surprising. Arterial hypertension is more prevalent among West Indians. ${ }^{22}$ Mortality from hypertension and cerebrovascular disease is high among immigrants from the West Indies and Africa. Mortality from ischaemic heart disease is high among immigrants from India and Pakistan. ${ }^{23}$ Diabetes is at least twice as prevalent in Indian Asians than in Europeans. ${ }^{2+}$ This will enhance the premature development of atherosclerosis and mortality from coronary heart disease. $^{25}$

Ethnic differences in statistics for hospital admissions for different respiratory diseases have been described. Jackson et al found asthma and respiratory tuberculosis to be particularly common among Asians, whereas West Indians suffered little carcinoma of the bronchus or bronchitis. ${ }^{26}$ The Royal College of General Practitioners' morbidity study found high standardised patient consultation ratios for respiratory disease among Asians. ${ }^{+}$Those Asian patients who consult do so more frequently. This may reflect understandable anxiety over respiratory symptoms in communities originating from countries where respiratory infections, particularly tuberculosis, remain a common cause of death. The high standardised patient consultation ratio for upper respiratory tract infection might equally reflect more infection in larger households or other factors.

Surveys suggest that immigrants from the Indian subcontinent and the Caribbean smoke less than the rest of the population in Britain (Office of Population Censuses and Surveys, general household survey, unpublished tables, 1975, 1976, 1978). The low rates of consultation for respiratory disease and bronchitis in West Indians may reflect this. The low standardised patient consultation ratio for otitis media is unexplained, though fewer children of West Indian descent present with upper respiratory tract infection generally $(p<0.05)$. This might be due to parents' differing perception of the need to consult, diagnostic oversight, or even anatomical differences and merits further investigation.

Early studies suggested a reduced prevalence of asthma in the children of Asian and West Indian families, in contrast with the raised standardised patient consultation ratios found in this study. Serial studies, however, have shown an increasing prevalence of childhood asthma over time. ${ }^{27}{ }^{28}$ Morrison-Smith and Cooper consider that differences in the prevalence of asthma and atopic disease can be explained on the basis of environmental conditions and are unlikely to be genetic. ${ }^{24}$ It seems that Asian and West Indian patients with asthma present more frequently to their general practitioner, but how this reflects the severity or control of their symptoms is unknown. The high standardised patient consultation ratios among West Indians for hay fever confirm the findings of Coffman and Chalmers of a higher prevalence of the disease in this group..$^{30}$

The high incidence of eczema in infants of West Indian descent has been contrasted previously with the apparent rarity of this condition in the West Indies. ${ }^{31}$

In contrast with the Royal College of General Practitioners' study, in which standardised consultation ratios and standardised patient consultation ratios for "symptoms and ill defined conditions" were found to be greatly raised among Asians,${ }^{+}$this study found only high standardised consultation ratios among Asians. As doctors become more adept at interpreting certain symptoms and patients come to articulate symptoms in a shared idiom, evidence of communication difficulties may diminish.

There is little published evidence that patients of immigrant descent make greater demands of general practitioners' services, $, 3: 32$ though general practitioners may find the problems peculiar to transcultural consultations more stressful. Patients from ethnic minorities are perceived as adding to workload. ${ }^{33}$ In this study standardised consultation rates were strikingly increased for male Asians and reduced for Irish and West Indian patients. Increased attendance for certain problems was counterbalanced by reduced attendance for others. Further research in this topic is necessary if different patients' needs are not to be overlooked. They have changed and are changing as cultural and environmental adaption results in more uniform patterns of morbidity and mortality.

The notion that "cultural differences" determine health inequalities is viewed with understandable suspicion, obscuring as it does disadvantages in employment, housing, and education facing ethnic minorities. Much mental illness, for example, may be interpreted as an intelligible response to racism and disadvantage. ${ }^{3+}$ A flexible framework must accommodate other demographic factors, the effects of migration, changing lifestyles from one generation to 
the next, and genetic differences as well as the realities of direct and indirect discrimination. A rigid approach is likely to hinder the process of adapting our health service to different needs. Furthermore, with few relevant community surveys we cannot know to what extent different patterns of consultation reflect real differences in health. They may reflect differing perceptions of illness, differing expectations of doctors, education, and previous experience. For example, Donovan found that "men of Afro-Caribbean descent are extremely sceptical of doctors' abilities to effect cures, and believe more in the body's own natural resistance. ${ }^{\prime \prime}$ The many factors contributing to sociocultural variation in consultation rates require more refined elucidation.

We acknowledge the help of the practice partners Drs Peter Brent, Derek Coffman, Jane Magill, and Peter Abrahams and administrative staff Steve Bruster, Conrad Harris, Debbie Hart, Sarah Castle, Nicola Dolliemore, and Tamara Stephan. Mrs Jane Wadsworth provided valuable statistical advice.

\section{Appendix}

The statistical significance of the difference between the standardised consultation ratios (SCRs) and standardised patient consultation ratios (SPCRs) of different ethnic groups was calculated in the following way. With the assumption that age specific rates are small the standard error (SE) of standardised consultation ratios (and standardised patient consultation ratios) can be shown to be:

SCR $/ \bar{r}$, where $r=$ total number of patients consulting.

The variance $\mathrm{SCR}=\mathrm{SCR} / \mathrm{r}$.

As the variance of a difference is the sum of the variances,

$$
\begin{aligned}
& \text { Variance }\left(S C R_{1}-S C R_{2}\right)=\frac{S C R_{1}^{2}}{r_{1}}+\frac{S C R_{2}}{r_{2}} \\
& \text { and } S E\left(S C R_{1}-S C R_{2}\right)=\sqrt{\frac{S C R_{1}^{2}}{r_{1}}+\frac{S_{C R}^{2}}{r_{2}}} .
\end{aligned}
$$

The standard normal deviate $(\mathrm{SND})$ of a difference $=$

Observed difference-Difference under null hypothesis $\mathrm{SE}$ of observed difference

$$
\mathrm{SND}\left(\mathrm{SCR}_{1}-\mathrm{SCR}_{2}\right)=\frac{\left(\mathrm{SCR}_{1}-\mathrm{SCR}_{2}\right)}{\sqrt{\frac{\mathrm{SCR}_{1}^{2}}{\mathrm{r}_{1}}+\frac{\mathrm{SCR}_{2}^{2}}{\mathrm{r}_{2}}}} .
$$

1 Webb P. Health problems of London's Asians and Afro-Caribbeans. Health lisitor 1981:54:1+1-7.

2 Pinsent R. Morhidity in an immigrant population. Lancet 1963;i: $437-8$.

3 Carne S. Immigrant patient and general practitioner. Proceedings of the Roval Societ of Medicine 1970;63:629-31.
+ Royal College of (ieneral Practitioners, Office of Population Censuses and Survers Department of Health and Sicial Security Morhidity sutistics from

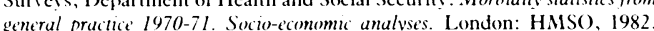
general practice 1970 -71. Socio-ecomomic analyses.

5 Murray J. Williams P. Self-reported illness and general practice consultations in Asian-horn and British-born residents of west London. Soc Psychiatry in Asian-horn
1986:21:139-45.

6 Blakemore $\mathrm{K}$. Ethnicity, self-reported illness and use of medical services by the elderly. P'ostgrad Med f 1983;59:668-70.

7 Johnson M. Cress M. Cardew S. Inner-city residents, ethnic minorities and primary health care. Postgrad Med 7 1983;59:664-7.

8 Harris C.I, Jarman B, Woodman E, White P, Fry JS. Prescribing-a suitable case for treatment. London: Roval College of General Practitioners, 1984 (Occasional paper No 24.)

9 World Health Organisation. Munual of the international statistical classification of discase's, injuries and causes of death. 9th revision, 1975. Geneva: WHO, 1977

10 Armitage P. Statistical methods in medical research. Oxford: Blackwell, 1971:388-9.

11 Cochrane P, Stopes-Roc M. Psychological symptom levels in Indian immigrants to England-a comparison with native English. Psvchol Med
1981;11:319-27.

12 Cochrane R. Mental illness in immigrants to England and Wales. Soc Pswchiatry 1977;12:25-37.

13 Cochrane R. Psichological and hehavioural disturbance in West Indians, Indians and Pakistanis in Britain: a comparison of rates among children and adults. Br f Psych 1979;134:201-10.

$1+$ Brewin C. Explaining the lower rates of psychiatric treatment among Asian immigrants to the United Kingdom: a preliminary study. So Psychiatry 1980;15:17-9.

15 Fuller JHS, Toon PID. Medical practice in a multicultural society. Oxford: Heinemann, 1988:191-3.

16 Rwegellera G(iC. Psychiatric morhidity among west Africans and West Indians living in London. Psychol Med 1977;7:317-29.

17 Carpenter L, Brockington IF. A study of mental illness in Asians, W'est Indians and Africans living in Manchester. Br f Psychiatry 1980;137:201-5.

18 Dean (G, W'alsch D, Downing H, Shellev E. First admissions of native-born and immigrants to pstchiatric hospitals in south-east England. $\mathrm{Br}$ Pswchiatry 1981;139:506-12.

19 Burke A. Racism and psychological disturbance among West Indians in Britain. In . F Soc Psychiatry 1984;30:50-68.

20 Littleweod R, Lipsedge M. Psychiatric illness among British Afro-Caribbeans. Br. Hed J 1988;296:950-1.

21 Kleinman $A$. Culture, depression and the "new" cross-cultural psschiatry. Soc Sci Med 1977;11:3-11.

22 Sever PS. Racial differences in blexd pressure: genetic and environmental factors. Postgrad Med f 1981;57:755-9.

23. Marmot MG, Adelstein AM, Busulu L. Cardiovascular mortality among immigrants to England and Wales. Postgrad Med $\mathcal{F}$ 1981;57:658-62.

24 Marmot MG, Adelstein AM, Busulu L. Lessons from the study of immigran mortality. Lancet $198+; \mathrm{i}: 1+55-7$.

25 Fox KMl, Shapiro LM. Heart discase in Asians in Britain. Br Med $\mathrm{f}$ 1988;297:311-2

26 Jackson S, Bannan L, Beevers D. Ethnic differences in respiratory discase. Postgrad Med J 1981:57:777-8.

27 Morrison-Smith J, Harding LK, Cumming G. The changing prevalence of asthma in school children. Clin Allergy 1971;1:57-61.

28 Morrison-Smith J. The prevalence of asthma and wheezing in children. Brf Dis ( hest 1976;70:73-7.

29 Morrison-Smith J. Cooper S. Asthma and atopic disease in immigrants from Asia and the West Indies. Postgrad .Med $\mathcal{f}$ 1981:57:774-6.

30) Coffman 1), (Chalmers CP. Incidence of hav fever in a north London practice. JR Cill (iin Pract 1974;24:171-80.

31 Davis LR, Marten RH, Sarkeny I. Atopic eczema in European and West Indian infants in London. Br f Dermatol 1961;73:410-4.

32 Donovan J. Ethnicity and health: a research review. Soc Sci Med 1984;19. 663-70.

33 Jarman B. Identification of underprivileged areas. Br Med $\mathcal{F}$ 1983;286:1705-9.

$3+$ Littlewood R, Lipsedge M. Aliens and alienists: ethnic minorities and pswchiutry. Harmondsworth: Penguin, 1982.

35 Donovan J. Black peoptes' health: a different approach. In: Rothwell 'I Phillips D, cds. Health, race and ethnicit. London: Methuen, 1986:117-35.

Accepled 22 August 1989

\section{ONE HUNDRED YEARS AGO}

An address was recently delivered to the students in a London hospital by the Rev. Edward White on the Spiritual Effects of Pain. The lecture included many suggestions well worthy of consideration by a larger circle than that to which it was originally delivered. Starting with the proposition that the human capacity for enjoyment necessarily involves that for specific suffering, he argues that, from the scheme of the Everlasting Cause, suffering cannot be excluded, but is a consistent extension of a method of government which is uniform. Mere Almighty benevolence he considers to be the mildest of all notions of an Eternal Power. The glory and force of ancient Judaism consisted in its assertion of Almighty Love, whose plan of ereation admitted of educational suffering, and of a redeeming energy ever crushing out the moral evil which is in the world. Educational pain $\pi(0) \mathrm{v} \eta$ pœena, penalty, as we all understand-no thinking medical man could spare this element from any scheme of moral government. But now comes the question, how far are we to go in eliminating pain, as seems the direction of our modern methods of education? Savage nations inflict the most horrible tortures on their young men to teach them endurance, and there is no question that most of our liberties and our highest privileges have been won for us in the past by fortitude learned in the school of suffering; a school which, in this age of comfort and coddling, seems in danger of closing its doors for want of pupils. The lecturer, in conclusion, asked two questions of a simple and practical nature about our modern anæsthetics. Does not their use in war tend to remove one of the restraints in the statesmen who control the policy of warlike nations? To which we unhesitatingly reply in the negative. The other question is not so easily answered. Mr. White asks: Are not the women who have been delivered under chloroform, and have never felt the martyrdom of prolonged parturition, to some extent deficient in the great and lifelong love which was the product of the "perilous birth?" He thinks they are, and he gives cases in point. Mr. White finely says that "Truth is ever bipolar, and softens as well as toughens," and he illustrates the maxim by examples of the beautiful tenderness learned in the seminary of physical and mental anguish, which can be readily confirmed by the experience of most medical practitioners. (British Medical Fournal 1889;i:728.) 